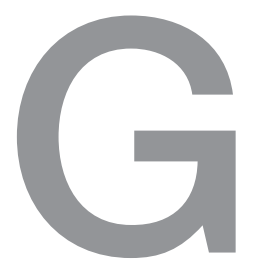

German
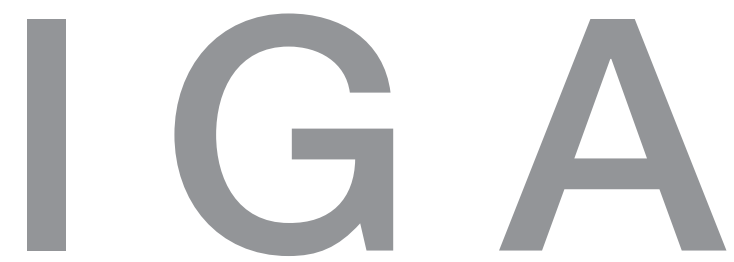

Working Papers

GIGA Research Programme:

Violence and Security

“Dreams Don't Come True in Eritrea": Anomie and Family Disintegration due to the Structural

Militarization of Society

Nicole Hirt

No 119

January 2010 


\section{GIGA Working Papers}

Edited by the

GIGA German Institute of Global and Area Studies

Leibniz-Institut für Globale und Regionale Studien

The GIGA Working Papers series serves to disseminate the research results of work in progress prior to publication in order to encourage the exchange of ideas and academic debate. An objective of the series is to get the findings out quickly, even if the presentations are less than fully polished. Inclusion of a paper in the GIGA Working Papers series does not constitute publication and should not limit publication in any other venue. Copyright remains with the authors. When working papers are eventually accepted by or published in a journal or book, the correct citation reference and, if possible, the corresponding link will then be included on the GIGA Working Papers website at <www.giga-hamburg.de/ workingpapers>.

GIGA research unit responsible for this issue:

Research Programme "Violence and Security"

Editor of the GIGA Working Papers series: Juliane Brach <workingpapers@giga-hamburg.de> Copyright for this issue: (C) Nicole Hirt

English copy editor: Melissa Nelson

Editorial assistant and production: Christine Berg

All GIGA Working Papers are available online and free of charge on the website $<w w w$. giga-hamburg.de/workingpapers $>$. They can also be ordered in print. A fee of $€ 5$ will be charged for production and postage costs. For orders or any requests please contact:

E-mail: workingpapers@giga-hamburg.de

Phone: ++49 (0)40 - 42825 - 548

The GIGA German Institute of Global and Area Studies cannot be held responsible for errors or any consequences arising from the use of information contained in this Working Paper; the views and opinions expressed are solely those of the author or authors and do not necessarily reflect those of the Institute.

GIGA German Institute of Global and Area Studies

Leibniz-Institut für Globale und Regionale Studien

Neuer Jungfernstieg 21

20354 Hamburg

Germany

E-mail: info@giga-hamburg.de

Website: www.giga-hamburg.de 


\title{
"Dreams Don't Come True in Eritrea": Anomie and Family Disintegration due to the Structural Militarization of Society
}

\begin{abstract}
This article analyzes contemporary Eritrea's acute crisis within the framework of the theory of anomie. It is based on the hypothesis that militarization, forced labor, mass exodus, and family disintegration can be interpreted as the consequences of two incompatible norm and value systems: the collectivist, nationalistic, and militaristic worldview of the former liberation front and ruling party People's Front for Democracy and Justice (PFDJ), and the traditional cultural system of Eritrea's society. In 2002 the regime introduced an unlimited "development campaign," thereby forcing large parts of the society to live as conscripts and perform unpaid labor. This has caused a mass exodus of young people and a rapid process of family disintegration. The article is based on empirical fieldwork and evaluates the ongoing developments, which have led to rapid economic decline and the destabilization of the entire fabric of society.
\end{abstract}

Keywords: Eritrea, militarization, forced labor, family disintegration, mass exodus, anomie

\section{Dr. Nicole Hirt}

is a political scientist and senior research fellow at the GIGA Institute of African Affairs.

Contact: hirt@giga-hamburg.de

Website: http://staff.giga-hamburg.de/hirt 


\section{Zusammenfassung}

\section{„In Eritrea werden keine Träume wahr": Anomie und Familiendesintegration als Folge der strukturellen Militarisierung der Gesellschaft}

Im vorliegenden Artikel wird die akute Krise, die Eritrea erfasst hat, im Rahmen der Anomietheorie analysiert. Der Text basiert auf der Hypothese, dass Militarisierung, Zwangsarbeit, Massenexodus und Familiendesintegration als Folgen zweier inkompatibler Normen- und Wertesysteme interpretiert werden können: der kollektivistischen, nationalistischen und militaristischen Weltanschauung der ehemaligen Befreiungsfront und nun regierenden People's Front for Democracy and Justice (PFDJ) und der traditionellen Wertordnung der eritreischen Gesellschaft. Im Jahr 2002 rief das Regime eine zeitlich unbegrenzte „Entwicklungskampagne“ aus, die große Teile der Bevölkerung zu unbezahlter Zwangsarbeit als Rekruten zwingt. Dies verursachte einen Massenexodus der jüngeren Generation und zu einem rapiden Prozess der familiären Desintegration. Der Artikel basiert auf empirischer Feldforschung und analysiert die aktuellen Entwicklungen, die zu einem rapiden ökonomischen Niedergang und einer Gefährdung des gesamtgesellschaftlichen Zusammenhangs führten. 


\title{
“Dreams Don't Come True in Eritrea": Anomie and Family Disintegration due to the Structural Militarization of Society
}

\author{
Nicole Hirt
}

\section{Article Outline}

1 Introduction

2 The Concept of Anomie

3 The Concept of Anomie in the Eritrean Context

4 The Impact of War, Militarization and National Service on Families and the Social System

5 Anomie Caused by the Warsay-Yikealo Development Campaign and Possible Coping Strategies

6 A Form of Forced Retreatism: The Increasing Number of Beggars as a Consequence of Anomie

7 Conclusions

\section{Introduction}

When a correspondent from the Financial Times visited Eritrea in summer 2009, a young woman told him, “When I was younger, I had hopes and dreams here. Now I don't expect anything. I take things as they come. Dreams don't come true in Eritrea."1 "When I was younger" refers to the time prior to the introduction of the Warsay-Yikealo Development Campaign (WYDC) in 2002, which was implemented two years after the end of a devastating war with Ethiopia (1998-2000). The youth of the country aspired to finally live life in peace,

1 FT.com Reportage: Inside the insular and secretive Eritrea, September 19, 2009, by Barney Jopson. 
to complete their educations, to have families, and to enjoy life together with their loved ones. Most of them were ready to fulfill their "national duty," 18 months of military training and reconstruction service, but then they expected to return to a civilian lifestyle.

In November 1991 the provisional government of Eritrea, formerly the Eritrea People's Liberation Front (EPLF), introduced a mandatory national service (Proclamation 18/1991) for all Eritreans, male and female, aged 18 to 40. Initially, this service included six months of military training and 12 months of work on reconstruction and development projects. One important aim of the national service is "to serve as an instrument for socializing Eritrean youth into the values and characteristics of the EPLF" (Gaim Kibreab 2009: 44). Although there has not been much enthusiasm for the program since its beginning, it was initially accepted as a national duty. In early 1998, a few months before the war with Ethiopia started, a national development campaign was announced and all those who had finished their national service were remobilized. When the war started, they were directly integrated into their specific army positions. Since the end of the war in 2000 there has been no significant demobilization of the army, ${ }^{2}$ which consists of more than 350,000 people, while every year new rounds of young men and women have been drafted (cf. Hughes 2005).

In summer 2002 the government announced the so-called Warsay-Yikealo Development Campaign. ${ }^{3}$ The younger generation is referred to as warsay, meaning "inheritor" or "follower," while yikealo denotes a wise elderly person, a term the government uses explicitly for the fighter generation. The younger generation is supposed to follow in the footsteps of the former fighters by internalizing and practicing the values of self-sacrifice, hard work and dedication to the Eritrean nation in the form of unlimited and unpaid service. The introduction of the WYDC meant de facto that the national service was no longer limited to 18 months (as a matter of fact, all those remobilized in 1998 had already spent years in the military) but rather became open-ended. With the exception of women over 27, married women, and those with children, all of whom are exempted from the service, only those with serious medical problems are discharged. The rest of the younger generation work on infrastructure projects or are employed at large cash-crop farms run by the army or at party-owned business enterprises in the construction service after completion of their military training. They receive a "salary" of approximately 500 nakfa per month (approximately €25) and live under military discipline even when working on civil activities. Some educated persons are allowed to perform their national service in the offices of the administration, but they still do not receive payment. Thus, it is the government, the PFDJ, the mass organizations, and the senior army officers that are the beneficiaries of the campaign. Party-owned construction firms operate mainly with national service conscripts. The four military command zones are involved

2 In 2002, approximately 5000 persons were demobilized, many of them women. In 2004, approximately 60,000 people were demobilized-most of them had already been working in government offices and did not change their type of work, but they received regular salaries after demobilization.

3 Eritrea Profile, 11.5.2002: Nation Launches Warsay-Yikealo Campaign, p. 1 
in economic activities such as trading, farming, property development and infrastructure construction, all of which are based on the unpaid labor of the conscripts. Before private firms were banned from the construction industry in April 2006, they could "hire" conscripts for employment - their wages being payable to the Ministry of Defense (Gaim Kibreab 2009: 62-63). Large parts of the population are thus unable to establish a family or care for their wives and children or their elderly parents. The way of life forced upon the recruits stands in stark contrast to the traditional forms of making a living. As this paper will explain, the WYDC is causing social anomie by making it impossible to reconcile private norms and values, such as concentrating on education and aspiring to a career, with the nationalist demands of the government. This creates a highly anomic situation in which traditional and national norms and demands are incompatible.

This paper first discusses the theoretical background - the concept of anomie developed by Durkheim, modified by Merton, and adapted to the context of authoritarian societies by Waldmann-and then applies it to the Eritrean context. Sections 4 and 5 analyze the profound anomie that has developed in the 2000s in the aftermath of the political clampdown on internal critics of the president and on journalists of the free press, and the totalitarization of the political system. In the absence of rule of law and the freedom to travel, crossing the borders illegally under the threat of death is the only alternative young Eritreans have if they want to escape the militarized life imposed on them. It is the only way in which returning to a life where basic cultural goals such as making a living for oneself and one's family can be realized, although it means violating the norms institutionalized by the government. The paper is supplemented by case studies which provide typical examples of how Eritreans are affected by the WYDC and their attempts to handle the situation. The case studies, which typify countless individual fates, make clear that even the simplest personal aspirations are unrealizable in today's Eritrea.

\section{The Concept of Anomie}

The term "anomie" was first applied by the French sociologist Emile Durkheim, most prominently in Suicide (1897). It describes a state of relative normlessness, or a lack of rules (dérèglement). Durkheim also described it as a "state of disturbed order" (Durkheim 1973: 289). He pointed out that anomie is not a sort of individual disease, but rather affects the state of a given society as a whole; individuals are too involved in the society to be healthy while the latter is sick (ibid.: 238).

The theory of anomie was further elaborated by Robert K. Merton in his work Social Theory and Social Structure, which first appeared in 1949. Merton claimed that deviation or deviant behavior is not a psychological abnormality but is linked to the state of a given society. His question was why the frequency of deviant behavior varies within different social structures, and why these deviations have different forms and patterns in different social structures 
(Merton 1965: 131-132). His central hypothesis was "that aberrant behavior may be regarded sociologically as a symptom of dissociation between culturally prescribed aspirations and socially structured avenues for realizing these aspirations" (ibid.: 134). A social condition in which culturally internalized goals cannot be reached by socially accepted means is described as anomie and favors deviant behavior. Merton's theoretical concept has often been applied in the framework of deviance in the form of criminality, but his approach was much more diverse. Choosing the United States of America as a case study, he stated that material wealth was seen as a basic symbol of success but legitimate ways to reach this goal were not equally distributed within the society. More generally, he observed that "it is only when a system of cultural values extols, virtually above all else, certain common success goals for the population at large while the social structure rigorously restricts or completely closes access to approved modes of reaching these goals for a considerable part of the same population that deviant behavior ensues on a large scale" (ibid.: 146). This situation may also arise in repressive political systems, especially when the rulers try to suppress traditional norms and values internalized by the majority of the population within a hybrid norm and value system, as we shall see is the case in Eritrea.

An important point in Merton's analysis is that there are various types of deviant behavior, far beyond criminality. In his scheme there are five modes of individual adaptation in order to deal with cultural goals and the institutionalized means to reach them:

1. Conformity: Both goals and institutionalized means are accepted-this is not deviant behavior.

2. Innovation: Cultural goals are internalized, but institutionalized norms are not equally internalized as the sole strategy for reaching these goals. In the US, for instance, there is a persistent open-class ideology which does not correspond with the real chances of the underprivileged parts of society. In order to reach the goal "success," "innovative" means such as criminality or corruption are applied.

3. Ritualism: Cultural goals are abandoned, while conformity of behavior is maintained. In order to avoid permanent frustration through unfulfilled ambition, the level of one's expectations is permanently lowered. It is a form of private escape, like the zealously conformist behavior of employees in the lower bureaucracy.

4. Retreatism: Both cultural goals and institutionalized means are abandoned. The individual drops out of society as, for example, psychotics, vagabonds or drug addicts do. According to Merton, retreatism most likely occurs when a person originally assimilated both cultural goals and institutional practices but experienced continued failure in nearing the goals through socially accepted measures and is unable to use an illegitimate route because of internalized prohibitions.

5. Rebellion: Alienation from both ruling goals and institutionalized means, which are replaced by alternative goals and mechanisms (Merton 1965: 140-157). 
These different kinds of deviant behavior will occur more often in a disintegrated society, where the social structure precludes forms of behavior demanded by the cultural structure. In this situation, there is a tendency towards the breakdown of existing norms and increasing normlessness, that is, social anomie (ibid.: 163). Merton stated that anomie is not a stagnant situation; rather, the emergence and growth of anomie are the results of an ongoing process. When deviant behavior proves "successful" (or remains unsanctioned), the legitimacy of institutional norms will be lessened or even eliminated, thus enlarging the extent of anomie in the system and the frequency of deviant behavior (ibid.: 180).

Peter Waldmann has taken up the concept of anomie with a focus on dictatorial systems and their impact on increasing anomie. He defines anomic situations as "those characterized by a lack of clear, consistent, socially accepted and enforceable rules or norms" (Waldmann 2003: 22; translation: N.H.). This definition of anomie does not contain Merton's assumption that it is not necessarily a lack of norms but rather a discrepancy between internalized norms and the institutionalized means for implementing them. Waldmann's definition, in other words, suggests that norms in anomic societies are unclear, inconsistent, not socially accepted, and not enforceable. It does not include the possibility that there may be a hybrid system of norms where one normative subsystem may be consistent and socially accepted while others, for example, those imposed by a dictatorial regime, may not be consistent and socially accepted but are enforced through state power. In this scenario, socially accepted norms do not correspond with the goals defined by the political power center and the values imposed by the government might force the individual to abandon internalized norms.

In the political context of a society ruled by a dictatorial regime, it thus makes sense not only to accept Waldmann's concept regarding the lack of clear and consistent rules and norms, but also to apply Merton's elaborated concept of a discrepancy between cultural (normative) structure and social structure. Moreover, the various forms of deviant behavior elaborated by Merton provide valuable indicators for measuring anomie. While rebellion may be hard to realize in an authoritarian or totalitarian context, innovation, ritualism, and retreatism can be good indicators of growing anomie. Ritualism, as a form of overconformity, overcompliance and overidentification with rules that results from anxiety and insecurity or in response to a situation which appears threatening (Merton 1965: 184), is a form of behavior which may be seen as being closely interlinked with authoritarian systems. Retreatism, which according to Merton often occurs in response to acute anomie "involving an abrupt break in the familiar and accepted normative framework and in established social relations, particularly when it appears to individuals that the condition will continue indefinitely" (ibid: 188), is also a possible response to dictatorial rule, especially after a system change or after a dictatorial regime carries out drastic measures.

Waldmann discusses the problems of empirical research based on the concept of anomie. He states that it is difficult to conceive of a society characterized by the lack of a consistent regulative system, especially in a dictatorship, which may appear "peaceful and quiet" at first 
glance. In order to detect an anomic system, the subjective feelings, psychological strain, or levels of suffering of individuals are decisive criteria. Direct or primary indicators are directly related to the normative structure of the group or society (Waldmann 2004: 26). There are also indirect or secondary indicators of anomie which can be deduced from empirical observation. If, for example, judges are poorly paid and have a bad reputation, law in general appears to be granted little respect in the society under investigation. The most important indirect indicators of an anomic situation are the different forms of deviant behavior that occur in the system, for instance, self-aggression or aggression towards others. Waldmann summarizes that the primary variables indicating anomie are a hybrid normative structure and reduced commitment to accepted norms; the different forms of deviant behavior are the secondary variables (Waldmann 2003: 26-29). Merton has also identified subjective and objective components of anomie, namely, personal feelings and life conditions (Merton 1965: 175).

\section{The Concept of Anomie in the Eritrean Context}

In regard to Eritrean society and its growing level of anomie, we ${ }^{4}$ rely on Merton's concept of anomie. One major reason for choosing his concept is the fact that Eritrean society does not suffer from normlessness or dérèglement; there is, rather, a hybrid system of norms and values strongly dominated by traditional norms, as we have shown in earlier research (Abdulkader Saleh et al.: 2008). There exists an elaborate set of customary laws and regulations which rule social life and conflict resolution. We assume that three distinguished norm and value systems exist in Eritrea:

1. The traditional norms and values of the various ethnic groups in the country.

2. The norms and values introduced by the EPLF during the armed struggle, which are based on a socialist ideology, nationalism, and the principle of self-reliance.

3. Liberal values of individualism and democracy, which have a certain impact on the educated urban population.

Until recently, and in spite of the numerous violent conflicts the population was exposed to in the past, inner-societal stability has been high and the degree of anomie low; a breakdown of the normative system has never occurred. This is mainly due to the perseverance of the traditional norms. Even the EPLF/PFDJ ${ }^{5}$ accepts the importance of customary institutions in

4 "We" in this paper refers to myself and my colleague Abdulkader Saleh, who is involved in the conceptualization and implementation of the research project.

5 At its third (and so far last) congress in 1994 the EPLF renamed itself the PFDJ (People's Front for Democracy and Justice), without making significant changes to its Marxist organizational structure. 
maintaining peace and stability in the country and tolerates traditional conflict-resolution mechanisms as long as the ruling party and its members are not impacted. ${ }^{6}$

The WYDC is a new strategy of total mobilization. It means extreme interference in the private lives of people and has a strong impact on the fabric of society, rendering individuals unable to follow long-established role expectations. The traditional norms cannot be applied in the national service, which is a form of collective life under military discipline quite different from community-oriented life. Moreover, the WYDC endangers the very existence of the entire population by forcing people into illegality for the simple purpose of earning money to sustain their families. Anomie is linked to situations where culturally prescribed aspirations and the socially structured means to realize these aspirations are dissociated, as culturally accepted goals cannot be reached using socially accepted means. In Eritrea, all generations including the youngest one have so far internalized and respected customary values. The lineage or extended family is the basic form of social belonging, and founding a family by following the traditional rituals is a basic societal goal. Of course, providing for one's family is another goal. Many Eritreans depend on support from their relatives in the diaspora, but they see it as their duty to contribute as much as they can to the wealth of their (extended) family. Education is also highly valued, more because of the honor and respect it generates than the material wealth it can bring. By introducing the WYDC, the government is now preventing a whole generation from reaching these internalized cultural goals through legitimate means. Avoiding indefinite military service is only possible if one lives as a draft dodger; bribes military commanders, if one has the financial capacity; works as a government spy; or flees the country. It is also evident that suicide rates are very high in the national service. The campaign has severely disturbed the cultural system and social structure, as the previously existing rules have been shattered by massive government intervention in normal life circles. As deviant behavior is a good secondary indicator of anomie, the four variations elaborated by Merton will be applied in the Eritrean context.

At first glance, there seems to have been no increase in deviant behavior if the term is reduced to criminality. Criminal acts have always been rare in Eritrea and still are. However, empirical research shows which forms of deviance occur frequently:

1. Innovation: There is growing corruption and a mentality of self-enrichment within the higher and middle strata of the PFDJ apparatus in the bureaucracy and the military. ${ }^{7}$ This can be interpreted as a sort of disillusion: the values the fighters internalized during the independence struggle, that is, reforming and liberating the society, have not material-

6 In 2004 the government even introduced so-called community courts headed by lay judges appointed by the ruling party. They are supposed to decide civil and criminal cases of lower importance (up to 100,000 nakfa in dispute) by applying customary law. The intention is to gain control over customary jurisdiction, which is usually executed by elders and mediators elected through customary procedures.

7 Eritrea ranked 126 out of 180 in Transparency International's 2008 corruption index, in spite of the government's goal of eradicating all forms of corruption. 
ized. Now individual interests are playing a growing role among a group of people who spent their life following the collectivist idea of being "fighters" (tegadelti). They have thus shifted their cultural value system from the collectivist ideals of the struggle towards privatized norms of personal well-being.

2. Ritualism: It is probable that many ex-fighters who internalized, at least partially, EPLF values concerning social revolution are dissatisfied with post-independence developments. Many of them are "frozen" (mediskal) employees who receive a salary but are not given any meaningful work because of their perceived political unreliability. Members of this group ritually perform the tasks they are ordered to without any feeling of personal responsibility or initiative (overconformity as a result of anxiety or insecurity). The loyalty of this group towards the system is probably still higher than that of the frustrated members of the national service, who do not see any sense in what they are doing and are deprived of their private lives but who nevertheless accept their situation due to internalized norms of obedience towards higher authorities.

3. Retreatism: Psychological stress and traumata, especially during the "border war," have led to numerous cases of mental illness, and there are many people with mental disturbances who can be seen as having dropped out of the system. Alcoholism is also widespread. Retreatist behavior is, however, limited by a strong net of family relationships which helps to avoid homelessness and complete neglect.

4. Rebellion: In a strongly authoritarian or totalitarian system like Eritrea's, open rebellion is virtually impossible; those who rebel face arrest and severe punishment. One form of rebellion exercised has been the massive movement of the population towards the Evangelical churches since the end of the Ethio-Eritrean War, something which is an indicator of alienation from both traditional values and the political values of the EPFL and a turn towards the alternative normative system provided by these religious communities. The same pattern applies to Muslims who have shifted towards the Wahabite ideology, which rejects the old traditions of Sufism. The harsh reaction of the government to these religious movements, including the arrest of more than 3,000 followers of "unregistered" churches and an unknown number of Muslims since 2002, indicates that it sees them as a serious threat to political stability in spite of their apolitical behavior. ${ }^{8}$

The mass flight of people in order to escape the national service can be seen as a form of innovation as institutionalized norms of serving one's country are permanently abandoned when those fleeing the country try to fulfill traditional expectations by settling in a foreign country to support the family from afar. In other cases, the flight is a form of re-

8 In 2008 more than 2000 members of unregistered minority religions banned in 2002 remained in incommunicado detention. At least 40 Muslim clerics and elders from the Saho ethnic group were arrested in August 2008 (Amnesty International 2009: 140). Hundreds of Muslims have been arrested over the years for alleged "Islamist radicalism," while the government has no problem with supporting the Islamist Al Shabaab militia in Somalia. 
bellion against a system that does not allow legal forms of protest. Both the traditional values and those of the EPLF are abandoned, while a Western lifestyle, which is already followed by parts of the diaspora, is adapted as an alternative cultural goal.

5. Conformity: According to Merton, a society can only be stable as long as conformity is the predominant form of behavior within it. In Eritrea it is most probable that the number of "conformists" is steadily declining: Those who have built their lives according to the cultural goals of the traditional society are no longer able to achieve these goals, as the means for reaching them have been destroyed by the structural militarization of the society. Those who have internalized EPLF norms, are convinced of the government's policy, and still believe that the goals of self-reliant development and social justice can be realized within the present system must turn a blind eye to the reality in the country, where the economy is on a steady course of decline and the number of beggars in the streets is rising on a daily basis. Generally, it is more likely that conformity of behavior can be identified among diaspora members who still believe that their government is on the right track as they are not directly exposed to its policies, yet are influenced by the regime's media propaganda.

\section{The Impact of War, Militarization and National Service on Families and the Social System}

The "border war" with Ethiopia (1998-2000) and the WYDC have had serious impacts on individuals and families; these range from resource conflicts, separation, loss of life and property, violence, and physical assault to the imprisonment and killing of those who try to cross the borders to neighboring countries. This section analyzes the anomic situation which has seized the organizational structure of Eritrean society's nuclear- and extended-family system. The first attempt of the EPLF/PFDJ to expand the influence of its norm and value system during and after the armed struggle failed because the fighters, though dominant in the state apparatus, were a minority in the country ${ }^{9}$ and the demobilization of the majority of combatants exposed them to the traditional structures they had come from. The values of the struggle were wartime values, developed by the leaders of a guerrilla army that lived under continuous threat of extinction, and it was easy to impose them on the rank and file fighters who were permanently exposed to political indoctrination. These values included self-sacrifice and the extinction of individualism; however, they also included positive values such as belonging to an egalitarian community entailing shared responsibility, shared property and gender equality with no distinctions along ethnic or religious lines. The primary loyalty of the fighters thus shifted from the extended family or clan to the Liberation Front. However, it

9 Towards the end of the liberation struggle in 1991, the EPLF's membership reached a peak of approximately 95,000 combatants, out of a population of approximately three million (Bruchhaus/Amanuel Mehreteab 2000). 
proved impossible for the leadership to convince the ex-fighters to maintain these values in peacetime, as they now had to take over the responsibility for their families and redevelop a sound individualism, while also relying on the support of the extended family. The government tried to provide material support for the demobilized, but it was unable to create a social environment that could reconcile both normative systems.

The war with Ethiopia and its aftermath brought a "second chance" for the PFDJ cadres to impose their rules on the entire society. The government introduced the national service in 1994, not only as military training and a development service but also as a tool for imposing the EPLF's values on the younger generation, especially in regard to overcoming "subnational" orientations-meaning loyalty to ethnic, regional and religious networks - and developing a culture of nationalism and self-sacrifice. The introduction of the WYDC in 2002 can be seen as an attempt to perpetuate the revolutionary wartime ideology and thus win a late victory over traditional values and sentiments. The name warsay-yikealo indicates that the younger generation, the inheritors, must live and work according to the advice of the older (and wiser) generation, but in a sense that excludes the civilian elders and defines the fighter generation as those who have all wisdom at their disposal. Even though they live in relative peace, the members of the younger generation are supposed to live in an enduring warsimulating situation. In an imitation of the situation in the field during the struggle, all civilian activities are subordinated to a militarized lifestyle. Individualism is bedeviled, and all personal interests must be negated.

It is, however, an obvious fact that this second attempt to impose the EPLF value system is about to fail and is leading to an ever greater state of social anomie, which is most clearly visible in the mass exodus of the younger generation. The large majority of the fighters joined the independence struggle voluntarily and was united by a common goal. They were convinced that in the end their extended families would profit from their efforts to liberate them from repression by the Ethiopian regime. If they got married and had children in the field, the EPLF took care of them. The warsay generation, however, has been forced into a lifestyle which not only seems senseless to them but also deprives them of hope for the future. Every individual, no matter how conservative and traditional his or her socialization has been, is now forced into military life, forced to leave his or her family and the responsibilities towards it behind, and forced to engage in activities which are simply imposed on him/her by military commanders. Even seeking comfort in religion has been prohibited, ${ }^{10}$ as this would run contrary to the PFDJ's nationalist ideology. It is an obvious fact that the promised rewards, such as the rapid development of the economy, food security, and national self-

10 In Sawa and the other military camps reading the Bible or the Quran is forbidden. In numerous cases those who refuse to hand over their respective holy books to the military officers have been arrested and placed in metal containers for punishment. For details of human rights violations in the military see Human Rights Watch: Service for Life. April 16, 2009, in: http://www.hrw.org/en/node/82280/section/6 (7.10.2009). 
reliance, are an illusion; the actual outcome of the campaign has been, on the contrary, a rapid decline in economic performance and the living standards of the population.

\section{Anomie Caused by the Warsay-Yikealo Development Campaign and Possible Coping Strategies}

Since the introduction of the indefinite national service, members of the younger generation have experienced a severe conflict of roles in attempting to fulfill their national obligation and to live a meaningful life by realizing their personal educational and career ambitions. Equally importantly, they have been deprived of the ability to contribute to their families' incomes. This section discusses the reactions and coping strategies evident as a result of the prevailing state of social anomie using Merton's categories of deviant behavior. It can be assumed that individuals have partially internalized both systems of norms, the traditional ones and those of the EPFL/PFDJ, but to varying degrees; this variation depends on the environment in which people were socialized and their degree of exposure to the party's ideology.

\subsection{Characteristic Features of Anomie}

Our empirical study examines primary (direct) indicators of anomie in relation to established norms and cultural goals. These indicators include feelings of dissatisfaction, insecurity, guilt, and depression. Secondary indicators, such as an increase in deviant behavior in the form of innovation, ritualism, retreatism and rebellion, will be demonstrated using case studies. As empirical research opportunities are extremely limited in present-day Eritrea, longterm participant observation is the most important research tool. The information presented in the case studies was partially gathered through narrative interviews, supplemented by long-term observation and target-oriented conversations. This paper presents five cases out of a sample of 14 . All names have been changed to grant anonymity, and in some cases specific characteristics have been changed in order to further protect the person's identity. However, Muslim and Christian names indicate the real religious affiliation of the individuals. In cases where conscripts had left Eritrea, close relatives of the refugees were asked about their whereabouts and the conditions under which they escaped. The information may not be accurate as to the exact details of the flight, but it reflects the general patterns often described by Eritreans who are now in exile. In one case information was derived from Internet messages sent by the person who had escaped.

Our sample of 14 case studies does not claim to be representative, but it does demonstrate features common to the majority of those affected by the WYDC. Seven members of the research sample were Muslim, seven were Christian. Five were women; nine were men. Among the women, three were national service recruits and two (both of them Muslim) had 
not registered for the service but both had husbands who were soldiers. Eight members of our sample had a grade-eleven education or higher, and the remaining six had no formal education, were housewives or maids, or worked in the agricultural sector before being conscripted. Nine people were from Asmara or had lived there for a long period; the rest were from a rural or semi-urban environment in the Southern Region. Seven of the sample group (all male) had escaped to Sudan by 2009. Four of them left Eritrea after we had included them in the sample without knowledge of their respective plans to flee, a fact which reflects the uncontrollable mass exodus that has begun in very recent times. The ages within our sample group ranged from 24 to 43 years, with an average age of 32 years. Those who were in the army and national service had served from two years up to 10.5 years, with an average length of five years (with the three cases doing only nominal service excluded). Among the men, the average duration of service was eight years. None of them had any hope of being released anytime in the near future.

In all cases, with the exception of three people who avoided serving in the WYDC by bribing officers or obtaining a medical exemption, the desired biography of the person in question has been severely disturbed: Eight members of the sample were deprived of the right to carry on their education or practice the profession they had studied; as a result, seven were unable to care for their family financially. One left his workplace due to severe mobbing and involuntary separation from his family, who lived in Sudan, as he was denied an exit-visa to visit them. In three cases, the national service led to divorce or separation from a partner, and one woman was widowed when her husband was shot while trying to cross the border.

All members of our sample group had experienced personal harm which ranged from a low to an extremely high degree of severity: five faced permanent separation from their family after fleeing the country; one was exposed to psychological harassment by his superiors; six males were arrested after a futile attempt to escape the military service; three were exposed to mistreatment in the military; and two women experienced sexual harassment in the military. These women had also faced social exclusion after their release, even though they managed to resist the advances of the military officers. Another woman had been mistreated by her husband, who had developed psychological problems while in the national service. One member of our sample group died, and the fate of another who ended up in Libya is unknown.

Our aim is not to show exceptional cases, and our sample was not selected to demonstrate particularly dramatic occurrences; similar stories can be heard in daily conversations and belong to the everyday experience of all Eritreans. In a highly anomic environment, all members of our sample group had to resort to deviant behavior in the sense of Merton in order to find a solution to their dilemma: Seven members of the sample had practiced innovative behavior by leaving the country in order to support their family from abroad. They maintained their traditional values and refused to accept the government's nationalist demands any longer. In two cases the flight can be seen as rebellion, as the people in question left Eritrea 
with the aspiration of leaving behind not only the national service but also the traditional expectations of their families. One man had reacted by divorcing his wife in order to give her a chance to remarry in order to resolve a clan conflict over his poor economic situation. One woman had managed to get pregnant while in the national service so that she would be released. She ended up in retreatism as she was unable to marry her boyfriend due to the resistance of her family; could not continue her education; and was ultimately dependent on her relatives, from whom she was alienated. Another woman had retreated from her aspirations of continuing her education and of finding a husband as socially accepted goals after being released from the service. One man had resorted to alcohol abuse and violence, which are also a sort of retreatism. Two women from a strongly conservative social environment had practiced innovation by taking up work to feed their children, even though this violated traditional role expectations. The following behavioral patterns are frequent as a consequence of the WYDC:

\subsection{Innovation}

Innovation is practiced when cultural goals are internalized but institutionalized norms are not equally internalized. Given the fact that the vast majority of the Eritrean population tries to achieve traditional cultural goals, a great deal of creativity is used to avoid the institutionally prescribed national service. Various strategies are utilized to avoid life as a recruit.

Innovation by Draft Dodging: Many young Eritreans try to avoid being conscripted into the army. They do not register for military service as they are required to do when they reach the age of 18; they hide from the security agents who are roaming the streets in search of civilians without exemption certificates; they do not report back to their military unit after their annual holiday has passed; they voluntarily fail in school exams in order to repeat a school year instead of going to Sawa ${ }^{11}$ for their twelfth school year. Girls marry at an early age and become pregnant-sometimes even without being married-in order to avoid the service. Thus, the government's military security employs a large number of secret agents whose sole task is to search for draft dodgers in streets, in bars, and by collecting information from draft dodgers' neighbors and acquaintances (cf. Treiber 2005). These agents are active throughout the year. Additionally, regular roundups called giffa are carried out, during which members of the military control the papers of passersby at all street corners and search private houses. One peculiar fact is that such roundups regularly take place in the weeks before Independence Day. While the population is expected to be in a festive mood, the streets of the capital are swarming with armed military personnel filling up the prisons with desperate draft dodgers.

11 Sawa is a military training camp in the western lowlands (Zoba Gash-Barka), where the military training usually takes place and where a boarding school for all twelfth-grade students was established in 2005. In everyday language, "going to Sawa" is equated with being a national service (agelglot) conscript. 
As the case of Halima shows, the arrest of draft dodgers can destroy entire families. Halima (30 years old) is from the Southern Region (Zoba Debub). In 1996, she married Ismail, a man from the same extended family who was an agro-pastoralist. He joined the army during the war with Ethiopia and was not demobilized. In 2003 he refused to go back to his military unit after a one-month vacation because his monthly salary of 450 nakfa (approximately €23) was too small to make a living. He worked illegally at a private construction firm and became one of the many wanted draft dodgers. He was arrested in 2005 on charges of betraying the nation and was sent to Wi'a, a military prison site. ${ }^{12}$ The family was cut off from the financial support provided by Ismail. The arrest of her husband changed everything for Halima and her two little daughters. She received occasional support from her husband's family, but it was not enough to cover her needs to survive. So she moved to Massawa, the coastal port city, to search for a job and to educate her children, which was only possible in an urban environment. While in jail, Halima's husband became displeased with her, as his family passed on false information regarding her activities in Massawa, ${ }^{13}$ where she was working as a housemaid. After one year imprisonment, Ismail was released and sent back to his military unit, which was stationed in Zoba Gash-Barka, near the Sudanese border. After four months of rehabilitation, that is, service under strict control to observe his behavior, he decided to risk his life and attempt to cross the border to Sudan with two of his friends. However, all three of them were shot and killed by border commandos. Halima was devastated when she received the news of Ismail's death, and her pain was exacerbated by the frequent queries of the children regarding their father. The three are now alienated from the extended family because of Halima's job and live under extremely poor economic conditions. The children will not be able to finish their education and will have to look for work as soon as possible.

Halima's case is an example of how state violence against national service recruits affects all family members, particularly women and children. The husband, for the sole "crime" of trying to feed his family, was jailed, alienated from his wife, and ultimately shot while trying to cross the border to find work in Sudan. His wife had to leave her place of origin and violate traditional role -expectations, against her will, by working as a housemaid. The children not only lost their father at an early age but also ended up in poverty and isolation.

Innovation by Trying to Avoid the Service: Exemptions are another way to escape the fate of being recruited into the national service. They are hard to obtain, as only persons who are considered physically or mentally unfit are exempted from the service. A council of military doctors decides who falls within this category. People try to get the certificate by pretending

12 Wi'a, situated in the Southern Red Sea Region and one of the hottest places on earth, is used as both a military training camp and a military prison.

13 The port city of Massawa is known as an urban area where prostitution is widespread; thus, the mere decision by a woman to seek a job there can lead to suspicion in her family that she might earn her income through prostitution. 
to be ill, mad, or overaggressive. Those who have the financial capacity try to bribe officials in order to be discharged. Some even accept being declared HIV-positive in order to escape the army. Another way people attain an informal exemption from the service is by bribing officers to allow them to enjoy extended periods of leave or to work in the administration, preferably in Asmara, where they can go about their own business while doing their service for only an hour a day. Sometimes young men are released when they can prove that they are the only breadwinner for their extended family, but it appears that this has no longer been accepted as an excuse in recent times.

The case of Mekonnen (36 years old) is typical of those who are "on the better side of life." Mekonnen comes from a well-to-do family in Asmara; his parents own a large electronics shop and have good relations with the government. During the 1990s, they opened a restaurant, which is managed by Mekonnen. When the war started in 1998, Mekonnen was conscripted like the other nationals but managed to get a job as the driver of a high-ranking officer, who employed him more or less nominally and who accepted bribes from his family in return for leaving him undisturbed. After the end of the war, Mekonnen was not demobilized but continued his nominal job. He is formally regarded as a national service recruit. About once a month he is called to drive the officer around for a few days; the rest of his time is at his own disposal, and he is free to get on with his business. He stresses that he is a soft and peaceful person and is glad that he never had to go through the hard military training. He feels content with his life, without considering his privileged position as something exceptional or unjust. His conviction is that whoever is in a position to avoid the national service will do so. However, even privileged persons such as Mekonnen are living under anomic conditions, as their maintenance of their comfortable lives and business enterprises is never secure. Large parts of the Asmara entertainment business (discos, nightclubs, etc.) are under the control of military officers, and the few private individuals who continue doing business in this field have to get along well with them at any cost as there is no legal security in the country.

Innovation by Exodus: Exodus is the last alternative for those who cannot deal with the situation any longer. Fleeing the country has become a mass phenomenon in recent years. Young people cross the borders to the neighboring countries under the threat of death. If they are discovered while trying to escape they may be shot on the spot or arrested and placed in a camp for an unspecified period, usually for about one year, only to be sent back to their military unit after the prison term is up. Torture, physical abuse, and beatings are common in military prison camps, although former inmates are reluctant to talk about what happened to them there, at least if they are still in Eritrea. ${ }^{14}$ Those who leave the country to escape from the national service put their families and parents in a critical situation. The parents are accused of facilitating the escape of their sons and daughters, either financially or

14 For human rights conditions and methods of torture and mistreatment, see Human Rights Watch 2009 and Amnesty International 2004. 
morally, which in the logic of the government is an act of treason. They are obliged to pay 50,000 nakfa $(€ 2,500)$ when one of their dependants escapes; otherwise they go to prison, unless they are released on bail. ${ }^{15}$ This punishment has been introduced as a subtle weapon to generate a moral conflict for those who feel responsible towards their relatives; however, given the desperate situation in the country, this strategy has not paid off. In very recent times the regime has seemingly had to drop this practice-at least for the time beingbecause the number of escapees has become so large that the prison facilities are no longer sufficient to house all affected parents. In 2008 almost 200,000 Eritrean refugees were registered in Sudan, not including the large number who had not reported to the authorities, to avoid living in a refugee camp, but had instead sought work in Khartoum and other large cities. Currently, at least 100 Eritreans arrive in Sudan on a daily basis. ${ }^{16}$ In Ethiopia, 21,000 Eritreans were registered as refugees in 2008, with numbers demonstrating an upward trend. Israel, a recently discovered destination, reported an influx of almost 4,500 Eritreans in 2008. Even Uganda now hosts close to 800 Eritreans. Many of those who manage to reach Sudan then try to make their way to Europe via the Sahara Desert to Libya and from there by boat to Malta or Italy. Accordingly, the number of registered Eritrean refugees in Italy rose from 94 in 2002 to 9,033 in 2008. The respective figures for Malta, which is infamous for having deported hundreds of Eritreans back to their country, are 7 for 2002 and 779 for 2008 . The numbers of Eritreans asking for asylum in Switzerland rose from 201 in 2002 to 2,471 in 2008; the figures for Sweden are 232 and 2,165, respectively. ${ }^{17}$ This list could be continued and does not indicate the complete number of refugees. There is without doubt an evident connection between the introduction of the WYDC and the steady increase in the number of Eritreans leaving their country.

The case of Ali (32 years old) is typical of those who try to leave the country by all means. Ali is from the Central Region (Zoba Ma'akel) and was recruited in 1997. He experienced the war with Ethiopia, and his two best friends lost their lives in the third Ethiopian offensive. After the peace agreement in 2000, his hope was to be demobilized, but he was kept in a military position. He felt desperate and made plans to escape with some like-minded friends. In 2004, when his military unit was shifted to Gash-Barka, some of the soldiers managed to cross the border, and he was supposed to join them. But on the night of the planned escape

15 Cf. Amnesty International, 21 Dec. 2006: Eritrea: Over 500 parents of conscripts arrested. AI Index AFR 64/015/2006.

16 Sudan Tribune: Important number of Eritrean and Ethiopian refugees arrive daily to Sudan, 21.8.2009. Informants residing in Sudan also confirmed this information. The number of 200,000 includes refugees of the independence struggle and the "border war" who reapplied for asylum in 2003, when the general refugee status of these groups was revoked. In 2007, 14,100 Eritrean new refugees registered in Sudan and 7,800 in Ethiopia (UNHCR 2008: 20, “2007 Global Trends: Refugees, asylum-seekers, returnees, internally displaced and stateless persons").

17 UNHCR statistical database, in: http://date.un.org/Data.aspx?q=refugees\&d=UNHCR\&f=indID\%3aType-Ref (21.09.2009). 
he was assigned to serve food and drink to the officers. At that time, his family's situation was miserable because his father, the wage earner, had become ill. The family had no money with which to seek adequate medical treatment. Ali's younger brother left school and began to work various jobs to support his family, doing hard labor on a daily-wage basis as his father had done before him. Some months later he was arrested because he had reached the age of 18 and had dropped out of school but had not reported for his national service. Ali felt ashamed that instead of supporting his family he himself had become a burden to them, as he as the eldest son was unable to assist his family. The only option he had to improve the financial situation was to try crossing the border and find employment in Sudan. Thus, it was only a matter of time before he made another attempt. Unfortunately, Ali was arrested at the border along with four others in 2005, and all of them were sent to prison for one year. When he was released, he was sent back to his unit. As he explained, it was hard for him to survive in the hostile environment of the military camp, where his superiors viewed him as a traitor. Finally, in late 2008, Ali managed to escape, together with two friends. His family learned about his flight from a relative in Sudan.

This case is a typical example of the incompatibility of the normative system imposed by the government and the civil normative structure which implies that the eldest son is responsible for maintaining the family when the father gets sick. Although Ali was not married, he experienced great psychological stress because he was not in a position to care for his parents and younger siblings. Furthermore, he was traumatized by his experiences during the war with Ethiopia and during his prison sentence. As the anomic pressure was very strong, he tried to flee at all costs. Ali's flight from the country was primarily a strategy of innovation. By working in Sudan he is able to fulfill his family's expectation that he will support them, a possibility he is denied in his own country.

\subsection{Ritualism}

Ritualistic behavior means that cultural goals are abandoned while conformity is maintained. It can be described as the overconformist behavior sometimes practiced by employees in the lower bureaucracy. In the Eritrean administration, there are numerous individuals who have been "frozen" (medeskal) by the government, which means they receive their salary but do not have any meaningful tasks as they have lost the confidence of their superiors. Nevertheless, they appear at their office every day, as they are deprived of alternatives. This pattern of behavior also applies to those national service recruits who accept their fate and never attempt to flee or overstretch their holidays. They either do not marry or neglect their families. Many of them suffer from psychological problems caused by delusion. Even many elementary and secondary school students refuse to attend school or study only half-heartedly be- 
cause they want to avoid being recruited into the military and having to work for the national service for an unlimited number of year once they have finished the twelfth grade. ${ }^{18}$

\subsection{Retreatism}

In the case of retreatism, both cultural goals and institutionalized means are abandoned. The individual drops out of society. Alcoholism, as one form of retreatism, is common among men who have given up trying to cope with the difficult situation. It is not uncommon to see drunken people in the streets of Asmara or other towns and cities. There are also less evident forms of alcohol abuse, but those who drink in their free time out of frustration often become aggressive towards their wives and children.

The case of Salma (35 years old) demonstrates the fate of a woman who has suffered from the violent behavior of her husband, who is trapped in the national service. Salma was married in 2002 at the age of 28 . Her husband Mohammed was 40 years old and had been conscripted since 1998; he received a payment of 500 nakfa per month, of which he was supposed to give 300 nakfa to his wife. Soon after the marriage, however, it became clear that he did not care to support Salma financially, even though she was pregnant. Mohammed had grown up in a rural environment in the Southern Region (Zoba Debub). Before joining the army, he had supported his family by cultivating and harvesting. Once in the military he started to drink, even though he was a Muslim from a conservative background. He was not satisfied with his life and was frustrated by his poor economic situation. After his marriage he took his frustrations out on his wife, as he could not fulfill her expectations and those of his clan. Having fallen into disrespect, he drowned his feelings in alcohol. Salma eventually had to move to her uncle's house in order to survive, and her daughter became sick due to being underweight. After six months, Mohammed suddenly decided to take his wife and daughter back to his house. He again mistreated Salma and did not give her food or clothing. According to their tradition, the extended families of the couple tried to keep the marriage together; however, Salma was now determined to get divorced. As the marriage had been held under Shari'a law, she turned to the Shari'a court to get the divorce. The court tried to appease her and justified the behavior of her husband with the fact that he was under national service. The husband was told to stop drinking and beating her. Mohammed refused to accept a divorce, as this would be an admission of his personal failure, but Salma refused to return to his house. Finally, in 2006, the leaders of Mohammed's clan intervened and convinced him to accept the divorce. Salma decided to take her life into her own hands and managed to find work as a housemaid, leaving her daughter with her uncle's family.

18 In 2009, 24,000 students attended the twelfth grade at Sawa. Only 3,000 of them passed the matriculation exam and are thus able to attend the technical colleges, the only form of tertiary education left in the country since the university was closed in 2006. The remaining 21,000 students will receive some educational training or be directly transferred to the army (source: informant; name withheld). 
Military recruits often develop psychological disturbances due to the conflict of roles they find themselves in. In this case the husband wanted to maintain his nominal role as the family head while leaving the responsibility for his wife and child to her uncle. His reaction is a typical case of retreatism. He was alienated from his cultural roots and retreated to alcohol abuse and aggression. In such cases, the Shari'a court, the traditional function of which is to mediate in family conflicts, finds itself in an ambiguous situation as national service conscripts are no longer in a position to maintain their families. By telling Mohammed to stop his excesses, the court tried to find a solution where no genuine solution was possible; even if Mohammed had done so, he would not have been able to live up to traditional expectations because his income was not sufficient to support his family. From Salma's point of view, her aspirations to lead a family life with a caring husband and several children were not fulfilled. She now finds herself in the difficult position of being a divorced woman with a child, something which makes it hard for her to remarry within her conservative cultural environment. Without the support of her extended family, she would have been unable to manage her life. Her fate is typical of the majority of mothers in Eritrea, who do not receive any support while their husbands are in the national service.

Retreatism in Cases of Psychological Trauma: Many young people have suffered psychological trauma and/or suffer from a mental disorder. A great deal of those who fought in the Ethio-Eritrean War were traumatized and did not receive adequate professional support to address this trauma (cf. Fleischhauer 2008). Equally traumatized were those women who suffered sexual assaults and rape. It is an open secret that involuntary relationships and rape occur in the military, but our respondents, thereby representing the attitude of the general public, were reluctant to report cases of sexual harassment because they are a social taboo and there is no chance that such assaults will be brought before a court. Young women who join the national service have to suffer this violence silently. If it becomes known that a woman has been a victim of rape, she is stigmatized and will have great difficulty finding a husband. Asia Abdulkadir, an Eritrean scholar who interviewed refugees in Sudan, has discovered that incidents of sexual violence in the military are frequent but that the women affected are reluctant to report them and completely unwilling to talk about their personal experiences (Asia Abdulkadir 2008: 86).

The case of Yordanos (33 years old) exemplifies the social stigmatization faced by female national service recruits. Born outside of a legal marriage, Yordanos grew up with her single mother in Asmara. Her mother worked as a hairdresser, and they lived in poverty. Yordanos was drafted into the military when the border war started in 1998. After the end of the war, she was kept in the national service and assigned to an officer to work as his maid. He soon started to make advances by complimenting her about her beauty. When she refused to start a relationship with him, he made her work in the hot sun for hours without rest. Yordanos felt desperate, but she was determined to defend herself and not to give in to his demands. After some time, she learned that her officer's superior was moving into a military camp 
some miles away. While she was on duty she managed to escape to that camp and tell her story to the superior officer. She was lucky, as he was more honorable than her immediate superior and she was transferred to another unit and demobilized in 2002. But now she faced isolation: although she had fought as a soldier in the war against Ethiopia, she was not honored by society; instead, she experienced stigmatization and exclusion. She began to work as a hairdresser like her mother, but she felt isolated and lonely and was barely able to make a living. Two years later she managed to go to Saudi Arabia, where she now works as a housemaid for a rich family. Yordanos was not able to fulfill any of her aspirations to lead a dignified life and improve her personal situation. She would have liked to get married and to have a beauty salon of her own, but due to her "career" in the military, people viewed her with even more suspicion than before. Her work in Saudi Arabia allows her to earn a relatively better income, but she is deprived of a private life, marriage and children and is completely at the disposal of her employers.

This case, which demonstrates the typical fate of many female conscripts, shows clearly that the so-called "heroines" of the war are in no way rewarded by the government, despite its nationalist and war-glorifying ideology. Once they return to civil life, these women's destiny is determined by traditional role expectations which they were forced to break against their will. Thus, women can either live up to the nationalist expectations of the state, thereby losing their dignity in the traditional society, or they can try to avoid the service, which means losing the chance to finalize their education and lead a self-determined life. All girls who want to finish their secondary education are forced to do so at the military training camp at Sawa. This is a further indication of the incompatibility of Eritrea's hybrid norm and value systems.

Retreatism in the form of suicide is the last resort for many of those trapped in the military. During the period from August 2008 to August 2009, we learned of 12 cases of suicide in different neighborhoods of Asmara, a number which indicates the prevalence of suicide. While young men often shoot or hang themselves, young women reportedly swallow liquid poison or burn themselves after pouring kerosene on their body and their clothes. The parents are not supposed to talk about how their children died, as the government wants to maintain the picture of the heroic youth serving their country with enthusiasm.

\subsection{Rebellion}

The mass exodus of many young people can also be seen as a form of rebellion, which in Merton's characterization means alienation from both ruling goals and institutionalized means, and the replacement of these with alternative goals and mechanisms. In some cases, young people leave the country to be free of both the traditional role expectations of their families and the government's nationalist expectation of self-sacrifice. Those who rebel against private and EPLF/PFDJ norms are more likely to be young women from the urban 
middle class and those who have not been thoroughly exposed to both the traditional and the government's norm systems, for instance, young Eritreans brought up in the diaspora whose parents returned with them during the 1990s.

One such case is that of Daniel (24 years old), the son of a family that resided in a European country for many years and returned soon after independence to build a new life in Eritrea. Unlike many Eritreans who lived abroad, Daniel's family did not acquire European citizenship for the family members, so Daniel had no chance to leave the country when he got into trouble. In 2002 he was 17 years old and frustrated with his life. He had never managed to thrive in the Eritrean school system, as he had spent his first school years in Europe, and he complained that the Eritrean system was very rigid and that teachers were hitting the students. He had no idea which professional career he should follow and longed to return to Europe. Daniel liked to spend the weekends at discos for some entertainment, but as he was only 17 and admission to discos was only granted from the age of 18 , he had somehow managed to get a false foreign passport indicating that he was 18 . This would turn out to be very unfortunate for him, as a security agent searching for draft dodgers discovered this fact and turned him in. Daniel was arrested for forgery of documents and kept in prison until he reached the age of 18 . He was then immediately sent to military training and was later kept in the national service. About four years later, in 2007, he managed to escape to Ethiopia with some friends from his military unit. He did not stay there but instead continued his journey to Sudan, where he hoped to be able to get support from relatives in Europe. After crossing the border from Ethiopia to Sudan, Daniel and his comrades were arrested by Sudanese border guards. The guards stripped the group of all their belongings but did not deport them to Eritrea. Daniel had a hard time but was able to make it to Khartoum, where he stayed throughout 2008. In 2009 he managed to get to Libya with the help of an organized human trafficking organization, which he paid for the transport across the Sahara Desert to Libya. From there he was able to inform his friends living in the diaspora that he intended to board a boat and continue his journey to Malta or Italy, like most Eritreans who try to make their way out of Sudan. Now Daniel faces two different risks: he may be arrested by the Libyan authorities like thousands of his countrymen, who subsequently remain stuck in Libyan prisons or refugee camps or are even deported to Eritrea ${ }^{19}$ or he may drown in the Mediterranean like hundreds of other illegal migrants who have tried in vain to reach European soil by boat. ${ }^{20}$

19 In 2008, some 700 Eritreans were held in the Misratah detention center in Libya. Amnesty International warned that 230 of them were about to be forcibly returned to Eritrea. Although the deportation did not take place, Eritreans are in a precarious situation in Libya, which is not a signatory of international treaties to protect the rights of refugees (Amnesty International public statement, 11 July 2008: Libya: Amnesty International warns against deportations of Eritreans, AI Index MDE 19/007/2008).

20 In August 2009, 73 Eritreans died on their passage from Libya to Italy after their boat ran out of fuel. They were not picked up by passing vessels or Italian boarder guards. Five people were rescued after having spent 
From the time of his youth, when his parents decided to return to Eritrea, Daniel has not been able to follow his own ambitions to finish his education in Europe and study a profession there; instead he had to spend the first years of his adult life in prison and in the military without being able to complete his secondary education. For the past three years of his life he has lived under insecure and precarious conditions, and it is unknown whether he will make it back to the European country where he was born. His attempt to make it anyway is a form of rebellion against both the government and his parents' aspirations to have him live in his mother country.

\section{A Form of Forced Retreatism: The Increasing Number of Beggars as a Consequence of Anomie}

During the 1990s the number of beggars in Asmara was small and Eritreans often stressed that they were proud not "to be a society of beggars." While only a small number of old men and women were begging in the streets, child beggars were almost unknown. Poor children were selling cigarettes, chewing gum, peanuts and the like to improve the income of their families, but they did not resort to directly asking people for money. The number of beggars in Asmara increased immediately after the war with Ethiopia, when hundreds of wardisplaced families fled to the cities and tried to survive by begging in front of churches and mosques, especially during religious festivities.

The gradual but continuous increase in begging which has taken place in recent years has coincided with the introduction of the WYDC. There has been a steady increase in the number of beggars from year to year, with a dramatic expansion of the phenomenon in 2009. ${ }^{21}$ As already explained, the Eritrean society's social security network is not based on a state welfare system but rather on solidarity networks among extended families within and outside the country. The prolonged national service has rendered this system defunct, as the members of the workforce are no longer earning enough money to support their families. In addition, increased divorce, out-of-wedlock pregnancies, and psychological disturbances are forcing more and more people to sit in the streets and beg for money.

The beggars sitting at street corners waiting for handouts are typically elderly women and young mothers with small children. The elderly women have fallen through the cracks of the social networks as their children have died in the war with Ethiopia, have left the country, are imprisoned, or have been kept in the national service and are unable to send money. The number of young mothers begging with their children has significantly increased over the past couple of years - even as recently as 2007 these women usually had only one very young

three weeks on the boat (http://www.welt.de/die-welt/politik/article4374514/Tote-Fluechtlinge-im-Mittelmeergesichtet.html).

21 This section is based on personal observation over extended periods between 1995 and 2009. 
child, indicating that the pregnancy had occurred outside a regular relationship and that they may have been rejected by their family and the father of the child. Recently more and more young mothers with several children, from babies up to five- or six-year-olds, have become beggars. The fact that they have two or three children is an indicator that these women are married, and that their husband is no longer able or willing to feed and house his family. He may be trapped in the national service, be serving a prison sentence for draft dodging, or be stranded in Sudan or another neighboring country without being able to remit money. Some male "dropouts" from the system are now hanging around in the streets in ragged clothes and showing signs of psychological illness, alcohol addiction and often aggressiveness. This is a phenomenon that first appeared on a significant scale after the end of the war and has since expanded due to untreated traumata. The prolonged national service may have similar effects, as the lack of any personal opportunities or possibilities for fulfilling one's familial duties also leads to traumatization and mental disorientation, something which is reflected in the demoralized people walking the streets unable to care for themselves. The army usually dismisses people who are unfit for the service due to massive psychological disturbances, leaving them without social or medical care.

Only in the past couple of years have children resorted to directly begging for money. According to the traditional values of Eritrean society, sending children out to beg is intolerable; it can thus be assumed that these children have parents who are unable to make ends meet for themselves and their families, and thus let their children go begging out of desperation. ${ }^{22}$ This is a further indicator of the familial disintegration caused by the so-called development campaign, which keeps husbands far from their families, meaning that the latter have to cope without any income or compensation from the government. In 2009 begging by persons who are not disintegrated from their family networks has also increased due to an overall increase in poverty. Given the high inflation rate and an extreme increase in the prices for basic consumer goods, even well-educated people dressed in suits and neat dresses are covertly begging when they see a chance. They approach seemingly well-off people and ask for money claim to be sick, that their business has been closed, or other similar stories. Many women try to earn a few nakfas by preparing $f u l$ (roasted peanuts) in the streets. Although selling ful at street corners and in bars in the evening has always been a way of earning income for the poor, the number of women doing this selling has increased dramatically in 2009.

In the summer of 2009 a large number of impoverished peasants from the countryside came to the city. They walked through the streets, sat around religious buildings, and knocked at private houses asking for food. These persons had been affected by the poor harvest of 2008, which was caused by drought but aggravated by land confiscation, the transformation of private subsistence agricultural fields into military-owned cash-crop plantations, and the absence of family members, who had been conscripted, from their own land, which they were

22 Children who are orphans are taken care of by the Ministry of Labour and Social Welfare, which places them in orphanages or foster families. 
supposed to till. In late 2008 staple foods were confiscated from the producers by the military in order to divert them to the market. In other cases, the Ministry of Agriculture seized the land of subsistence farmers under its policy of rationalizing agricultural production; it claimed that it would work the land using conscripts and pay the peasants compensation, something which did not occur. While the so-called community shops in Asmara distribute subsidized food to citizens, there are no such services in the countryside, where the producers depend on their own harvest to make a living and sell surplus grain in order to be able to buy nonfood items and coffee, cooking oil, etc. The national service has disrupted the entire subsistence-farming and pastoral-production system, as all able-bodied men are serving in the army while women and elderly people are trying to keep up production. The result is an influx of destitute people into the cities, the likes of which has been unknown since Eritrea's independence.

\section{Conclusions}

In the period since 1961 the Eritrean people have experienced 30 years of a liberation struggle, a short period of peace that lasted for seven years, two years of a devastating "border war" with Ethiopia, and nine years of a no-war/no-peace situation. Remarkably, the level of societal disintegration during these challenging times has never been as high as during recent years, namely, since the introduction of the WYDC. During the liberation struggle, the vast majority of the fighters went to the field as volunteers and were convinced that they were fighting not only for national independence but also for a social revolution and the betterment of their people and families. When independence was achieved in 1991, there was hope for a better future. The majority believed that slow but steady economic development and the liberalization of the political system would occur. During the war with Ethiopia, most of the soldiers were still convinced that an independent Eritrea was worth fighting for in the face of the threat of a new Ethiopian invasion. Immediately after the Algiers Peace Agreement in 2000, Eritreans became impatient: they wanted to see progress in the field of democratization and challenged the political elite's culture of secrecy. After large areas of the state's territory were invaded by the Ethiopian army in May 2000 and some officials openly claimed that "Eritrea had lost the war," the PFDJ lost its image of invincibility; this resulted in the public's demand for self-criticism on the part of the government and the broader participation of the hafash, the Eritrean masses, in public affairs. The president reacted with a clampdown on the free press and the arrest of his most prominent adversaries within the political elite, the G15, in September 2001. ${ }^{23}$ The next step towards totalitarianism was the in-

23 The so-called G15 is a dissident group whose members held high positions in the party, government and military and demanded inter alia the implementation of the 1997 constitution. For details, see Amnesty Interna- 
troduction of the WYDC in summer 2002. Its implementation was justified with the unsolved conflict with Ethiopia, as Ethiopia's prime minister Meles Zenawi did not accept the verdict of an international border commission and was not ready to cede territory awarded to Eritrea. The Eritrean government reacted by abandoning plans for demobilization and by recruiting more youngsters into the army every year. In 2007 Eritrean president Isayas Afewerki declared the border issue between Eritrea and Ethiopia "solved." He claimed that there was no longer conflict as the border had been virtually demarcated and there was no danger of a future war. ${ }^{24}$ Still, he saw no necessity of demobilizing an army of more than 350,000 conscripts. The government has since effectively turned the economy into a party- and military-controlled venture based on the "free" labor provided by the warsay generation. Forced labor has replaced the free labor market, especially in the fields of cash-crop agriculture and in construction (Gaim Kibreab 2009). As demonstrated in this article, this has led to a rapid increase in anomie and family disintegration and to the spectacular mass exodus of the younger generation.

It is hard to grasp the logic of this social experiment. The unlimited service completely undermines the morale of the armed forces: instead of defending the country against the Woyane (the Ethiopian government led by the Tigray People's Liberation Front), conscripts dream of fleeing to the neighboring countries to escape their fate. If the Eritrean government's primary aspiration was to train a reliable defense force, it could have maintained the original 18-month duration of the service, with occasional training sessions for reservists. The official argument for the campaign is that in order to rebuild the war-devastated country within the framework of the government's self-reliance strategy, voluntary labor is necessary for sufficient infrastructure construction to initiate a process of development. At the same time, the economy is being strangled under a command economy that heavily restricts the private sector and foreign investment. What is worse is that the national service recruits do not even receive a salary adequate to support themselves, not to mention their nuclear and extended families. There is no longer any "normality" of life: one can no longer live up to the general norms and values without breaking the laws of the government. As Eritrean society has always lived under stress, it has developed a remarkable capacity to survive under adverse conditions. This time, however, people do not feel that they are fighting against an occupying enemy force and for the improvement of their lives; rather, it is their own government, the former liberator, which has made their lives miserable. The only plausible justification for the ruling elite of the country to continue turning a blind eye to the rapid downward spiral they have initiated is their desire to force the values of the liberation struggle upon the younger generation and to thereby gain control over each and every individual who poses a

tional: Eritrea. "You have no right to ask"-Government resists scrutiny on human rights. AI Index AFR 64/003/2004.

24 Interview with Al Arabiya, 10 May 2007, in: http://www.somalicongress.org/article518.html?debut_articles_ rubrique $=60(5.10 .2009)$. 
potential threat to the ruling group. The negative consequences of this strategy are affecting the economy, the educational sector, and the core of societal organization. They will be felt for years to come if no immediate policy changes are introduced, an action which is unlikely under the present leadership. 


\section{References}

Abdulkader Saleh / Hirt, Nicole (2009): Conflict Resolution and Customary Law in Contemporary Eritrea: Case Studies of the Saho Community. Paper presented at the III. EnnoLittmann Conference, FU Berlin, 1. - 4. April (forthcoming).

Abdulkader Saleh / Hirt, Nicole (2008): Zones of Peace in a Region of Conflict and Crisis: The Role of Eritrean Civil Society Reviewed, in: Bruchhaus, Eva Maria / Sommer, Monika (eds.): Hot Spot Horn of Africa Revisited. Approaches to Make Sense of Conflict. Münster: Lit, pp. $263-279$.

Abdulkader Saleh / Hirt, Nicole / Smidt, Wolbert / Tetzlaff, Rainer (eds.) (2008): Friedenszonen in Eritrea und Tigray unter Druck - Identitätskonstruktion, soziale Kohäsion und politische Stabilität. Berlin/Münster: Lit.

Amnesty International: Eritrea. 'You have no right to ask' - Government resists scrutiny on human rights. AI Index: AFR 64/003/2004.

Asia Abdulkadir (2008): Die Perzeption von Gewalt im Geschlechterverhältnis in Eritrea. Eine Untersuchung über die Gewalterfahrung weiblicher Rekrutinnen. Hamburg: Kovac, J.

Bruchhaus, Eva Maria / Sommer, Monika (eds.) (2008): Hot Spot Horn of Africa Revisited. Approaches to Make Sense of Conflict. Münster: Lit.

Bruchhaus, Eva Maria / Sommer, Monika (eds.) (2003): Hot Spot Horn of Africa. Between Integration and Disintegration. Münster: Lit.

Bruchhaus, Eva-Maria / Amanuel Mehreteab (2000): Leaving the Warm House. The Impact of Demobilization in Eritrea, in: Kingma, Kees (ed.): Demobilization in Sub-Saharan Africa: the Development and Security Impacts. Basingstoke: MacMillan Press, pp. 95-131.

Durkheim, Emile (1897): Le Suicide. Paris: Les presses universitaires du France.

Entner, Michaela (2001): Der eritreisch-äthiopische Krieg 1998 - 2000. Freiburg: Arnold Bergstraesser Institut, Freiburger Beiträge zu Entwicklung und Politik, 28.

EPLF (1994): A National Charter for Eritrea. For a Democratic, Just and Prosperous Future. Approved by the Third Congress of the Eritrean People's Liberation Front (EPLF).Nacfa.

Favali, Lyda / Pateman, Roy (2003): Blood, Land and Sex. Legal and Political Pluralism in Eritrea. Bloomington, IN and Indianapolis: Indiana University Press.

Fleischhauer, Johanna (2008): Vom Krieg betroffene Kinder. Eine vernachlässigte Dimension von Friedenskonsolidierung. Eine Untersuchung psychosozialer Intervention für Kinder während und nach bewaffneten Konflikten am Beispiel Eritreas. Opladen and Farmington Hills: Budrich UniPress.

Frieß, Hans-Jürgen (2003): Gesellschaftliche Doppelmoral und politische Stabilität. Das Castro-Regime auf Kuba, in: Waldmann, Peter (ed.) (2003): Diktatur, Demokratisierung und soziale Anomie. München: Ernst Vögel, pp. 95-120. 
Gaim Kibreab (2009): Forced Labour in Eritrea, in: Journal of Modern African Studies, vol. 47, no. 1, pp. 41-72.

Gilkes, Patrick / Plaut, Martin (1999): War in the Horn: The Conflict between Eritrea and Ethiopia. London: Royal Institute of International Affairs Discussion Papers.

Hirt, Nicole (2001): Eritrea zwischen Krieg und Frieden. Die Entwicklung seit der Unabhängigkeit. Hamburg: Institut für Afrika-Kunde.

Hughes, Howard (2005): Eine Volksarmee der besonderen Art - der Militärkomplex in Eritrea, in: KDV May 2005, www.Connection-ev.de/Afrika/eri_militaer.html (4.1.2010).

Human Rights Watch (2009): Service for Life. State Repression and Indefinite Conscription in Eritrea, http://www.hrw.org (4.1.2010).

Kidane Mengisteab / Okbazghi Yohannes (2005): Anatomy of an African Tragedy. Political, Economic and Foreign Policy Crisis in Post-Independence Eritrea. Trenton, NJ: Red Sea Press.

Linz, Juan José (2000): Totalitäre und autoritäre Regime. Potsdamer Textbücher, vol. 4, Berlin: Debatte Verlag.

Merton, Robert K. (1965): Social Theory and Social Structure. Rev. and enl. ed., 9 pr., New York, NY: Free Press.

Müller, Tanja (2005): The Making of Elite Women: Revolution and Nation Building in Eritrea. Leiden: Brill.

Pool, David (2001): From Guerillas to Government. The Eritrean People's Liberation Front. East African Studies. Athens: Ohio University Press.

Redeker Hepner, Tricia (2009): Soldiers, Martyrs, Traitors, and Exiles. Political Conflict in Eritrea and the Diaspora. Philadelphia: University of Pennsylvania Press.

Treiber, Magnus (2005): Der Traum vom guten Leben. Die eritreische warsay-Generation im Asmara der zweiten Nachkriegszeit. Münster: Lit.

Tronvoll, Kjetl (2009): The Lasting Struggle for Freedom in Eritrea. Human Rights and Political Development, 1991-2009. Oslo: The Oslo Centre for Peace and Human Rights.

Waldmann, Peter (ed.) (2003): Diktatur, Demokratisierung und soziale Anomie. München: Ernst Vögel.

Waldmann, Peter (1998): Soziale Anomie. Zur Fruchtbarkeit eines klassischen soziologischen Konzepts in Bezug auf die Entwicklungsländer, in: Geschichte und Gegenwart. Vierteljahreshefte für Zeitgeschichte, Gesellschaftsanalyse und politische Bildung, vol. 17, no. 3, August 1998, pp. 143-164. 


\section{G

\section{Recent Issues}

No 118 Miriam Shabafrouz: Oil and the Eruption of the Algerian Civil War: A Context-sensitive Analysis of the Ambivalent Impact of Resource Abundance; January 2010

No 117 Daniel Flemes and Michael Radseck: Creating Multilevel Security Governance in South America; December 2009

No 116 Andreas Mehler: Reshaping Political Space? The Impact of the Armed Insurgency in the Central African Republic on Political Parties and Representation; December 2009

No 115 Malte Gephart: Contextualizing Conceptions of Corruption: Challenges for the International Anti-corruption Campaign; December 2009

No 114 Andreas Mehler: The Production of Insecurity by African Security Forces: Insights from Liberia and the Central African Republic; November 2009

No 113 Miriam Shabafrouz: Iran's Oil Wealth: Treasure and Trouble for the Shah's Regime. A Context-sensitive Analysis of the Ambivalent Impact of Resource Abundance; November 2009

No 112 Annegret Mähler: Oil in Venezuela: Triggering Violence or Ensuring Stability? A Contextsensitive Analysis of the Ambivalent Impact of Resource Abundance; October 2009

No 111 Martin Beck: Oil-rent Boom in Iran?; October 2009

No 110 Juliane Brach and Robert Kappel: Global Value Chains, Technology Transfer and Local Firm Upgrading in Non-OECD Countries; October 2009

No 109 Heinz Jockers, Dirk Kohnert and Paul Nugent: The Successful Ghana Election of 2008 - a Convenient Myth? Ethnicity in Ghana's Elections Revisited; September 2009

No 108 Sebastian Huhn: The Culture of Fear and Control in Costa Rica (II): The Talk of Crime and Social Changes; September 2009

No 107 David Shim: Shrimp amongst Whales? Assessing South Korea's Regional-power Status; August 2009

No 106 Günter Schucher: Where Minds Meet: The "Professionalization" of Cross-Strait Academic Exchange; August 2009

No 105 Alexander Stroh: The Effects of Electoral Institutions in Rwanda: Why Proportional Representation Supports the Authoritarian Regime; July 2009

All GIGA Working Papers are available free of charge at www.giga-hamburg.de/workingpapers. For any requests please contact: workingpapers@giga-hamburg.de.

Editor of the Working Paper Series: Juliane Brach 